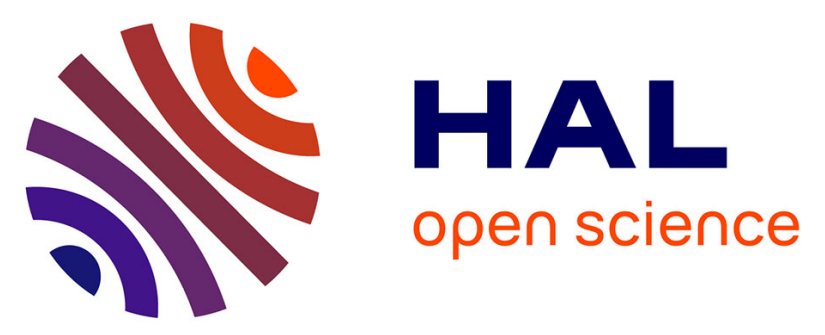

\title{
A Combined Experimental and Theoretical Study of the Ammonium Bifluoride Catalyzed Regioselective Synthesis of Quinoxalines and Pyrido[2,3-b]pyrazines
}

Frédéric Lassagne, Floris Chevallier, Thierry Roisnel, Vincent Dorcet, Florence Mongin, Luis R Domingo

\section{To cite this version:}

Frédéric Lassagne, Floris Chevallier, Thierry Roisnel, Vincent Dorcet, Florence Mongin, et al.. A Combined Experimental and Theoretical Study of the Ammonium Bifluoride Catalyzed Regioselective Synthesis of Quinoxalines and Pyrido[2,3-b]pyrazines. Synthesis: Journal of Synthetic Organic Chemistry, 2015, 47 (17), pp.2680-2689. 10.1055/s-0034-1380678 . hal-01248104

HAL Id: hal-01248104

https://hal-univ-rennes1.archives-ouvertes.fr/hal-01248104

Submitted on 31 Dec 2015

HAL is a multi-disciplinary open access archive for the deposit and dissemination of scientific research documents, whether they are published or not. The documents may come from teaching and research institutions in France or abroad, or from public or private research centers.
L'archive ouverte pluridisciplinaire HAL, est destinée au dépôt et à la diffusion de documents scientifiques de niveau recherche, publiés ou non, émanant des établissements d'enseignement et de recherche français ou étrangers, des laboratoires publics ou privés. 


\title{
A Combined Experimental and Theoretical Study of the Ammonium- Bifluoride-Catalyzed Regioselective Synthesis of Quinoxalines and Pyrido[2,3-b]pyrazines
}

\author{
Frédéric Lassagne, ${ }^{* \mathrm{a}}$ Floris Chevallier, ${ }^{\mathrm{a}}$ Thierry Roisnel, ${ }^{\mathrm{b}}$ Vincent Dorcet, ${ }^{\mathrm{b}}$ Florence Mongin, ${ }^{*^{\mathrm{a}}}$ Luis R. Domingo ${ }^{* \mathrm{c}}$ \\ ${ }^{a}$ Chimie et Photonique Moléculaires, Institut des Sciences Chimiques de Rennes, UMR 6226, Université de Rennes 1-CNRS, Bâtiment \\ 10A, Case 1003, Campus de Beaulieu, 35042 Rennes, France \\ ${ }^{\mathrm{b}}$ Centre de Diffractométrie X, Institut des Sciences Chimiques de Rennes, UMR 6226, Université de Rennes 1-CNRS, Bâtiment 10B, \\ Case 1003, Campus de Beaulieu, 35042 Rennes, France \\ ${ }^{\mathrm{c}}$ Universidad de Valencia, Departamento de Química Orgánica, Dr. Moliner 50, E-46100 Burjassot, Valencia, Spain \\ Fax: +33223236955 \\ E-mail: frederic.lassagne@univ-rennes1.fr, florence.mongin@univ-rennes1.fr, domingo@utopia.uv.es \\ Received: The date will be inserted once the manuscript is accepted.
}

\begin{abstract}
Ammonium bifluoride was efficiently used (at a 0.5 mol \% loading) to catalyze the cyclocondensation between 1,2arylenediamines and 1,2-dicarbonyl compounds at room temperature in methanol-water, affording quinoxalines and pyrido[2,3-b]pyrazines in excellent yields. Importantly, 2,8disubstituted quinoxalines and 3-substituted pyrido[2,3$b]$ pyrazines were regioselectively formed by reacting aryl glyoxals with 3-methyl-1,2-phenylenediamine and 2,3diaminopyridine, respectively. Analysis of the DFT reactivity indices allowed to explain the catalytic role of ammonium bifluoride.
\end{abstract}

Key words: quinoxalines, pyrido[2,3-b]pyrazines, regioselectivity, ammonium bifluoride, catalysis, DFT reactivity indices

Quinoxalines and pyrido[2,3- $b]$ pyrazines belong to an important class of nitrogen heterocyclic compounds. Derivatives are endowed with interesting biological activities $^{1}$ and used in therapeutics. Others serve as intermediates to targets such as organic dyes, ${ }^{2}$ electroluminescent materials, ${ }^{3}$ and semiconductors. ${ }^{4}$ The most common synthetic route used to reach these structures is the condensation of 1,2-dicarbonyl reagents with 1,2-arylenediamines in refluxing ethanol or acetic acid (Scheme 1). ${ }^{5}$

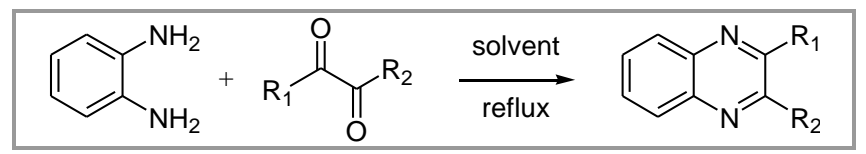

Scheme 1 Most common synthetic route to 2,3-disubstituted quinoxalines

In these last years, a large range of catalysts, ${ }^{6}$ as well as green processes, ${ }^{7}$ have been developed to carry out this reaction. A few studies have also been devoted to reactions in which regioselectivity can be an issue. In particular, 2,8-disubstituted quinoxalines were regioselectively synthesized from 2,3-diaminobenzoic acid and aryl glyoxals, at methanol reflux, by Wang and co-workers. ${ }^{8}$ Besides, 3-substituted pyrido[2,3$b]$ pyrazines were similarly formed from 2,3diaminopyridine. ${ }^{9}$

A few examples in the literature state the use of bifluoride anion. Among them, $\mathrm{Bu}_{4} \mathrm{NHF}_{2}$ was recognized as a fluorinating reagent. ${ }^{10}$ More recently, quaternary ammonium bifluorides were identified as catalysts for asymmetric nitroaldol reaction of silyl nitronates to aldehydes. ${ }^{11}$ To our knowledge, $\mathrm{NH}_{4} \mathrm{HF}_{2}$ (ammonium bifluoride or ammonium hydrogen fluoride, $\mathrm{ABF}$ ) was only used recently as Brönsted acid catalyst in organic synthesis. ${ }^{12}$ In the course of testing numerous ammonium salts as Brönsted acid sources for condensation to quinoxaline, we identified $\mathrm{ABF}$ as a good candidate, and here report the results of the study. In addition, the high regioselectivities noted for the reaction using either 3-methyl-1,2phenylenediamine or 2,3-diaminopyridine with unsymmetrical 1,2-dicarbonyl compounds were rationalized.

An experimental study of the ABF-catalyzed condensation reactions.

The condensation of 1,2-phenylenediamine (1a) to benzil (2a) in the presence of ABF (1 mol \%) at room temperature was first selected to optimize the reaction solvent (Scheme 2, Table 1). Three polar media, which are water, 4:1 methanol-water, and 4:1 ethanolwater, were compared: in the two organic solvents, quantitative yields of $\mathbf{3 a}$ were obtained in 5 and 15 min, respectively (Table 1 , entries 1,2 ) while in pure water a lower $80 \%$ yield was recorded, even after 1 hour reaction (Table 1, entry 3). In 4:1 methanol-water and $4: 1$ ethanol-water, the amount of catalyst could even be reduced to $0.5 \mathrm{~mol} \%$ provided that extended reaction times of 15 and $30 \mathrm{~min}$ are used (Table 1, entries 4,5). Dichloromethane and ethyl acetate were also evaluated: in these solvents, the reaction proved less efficient, and increasing the catalyst loading to 10 mol $\%$ and the reaction time to $1 \mathrm{~h}$ only led to $90 \%$ yields (Table 1, entries 6,7).

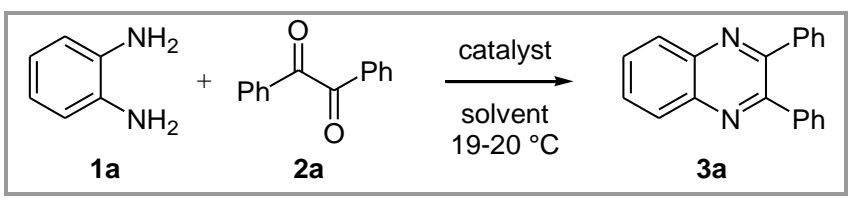

Scheme 2 Optimization of the synthesis of 2,3diphenylquinoxaline using $\mathrm{ABF}$ 


\begin{tabular}{|c|c|c|c|c|}
\hline Entry & Solvent & $\mathrm{ABF}(\mathrm{mol} \%)$ & Time (min) & Yield (\%) \\
\hline 1 & 4:1 MeOH- $\mathrm{H}_{2} \mathrm{O}$ & 1 & 5 & $>99$ \\
\hline 2 & 4:1 EtOH- $\mathrm{H}_{2} \mathrm{O}$ & 1 & 15 & $>99$ \\
\hline 3 & $\mathrm{H}_{2} \mathrm{O}$ & 1 & 60 or more & 80 \\
\hline 4 & 4:1 MeOH- $\mathrm{H}_{2} \mathrm{O}$ & 0.5 & 15 & $>99$ \\
\hline 5 & 4:1 EtOH- $\mathrm{H}_{2} \mathrm{O}$ & 0.5 & 30 & $>99$ \\
\hline 6 & $\mathrm{CH}_{2} \mathrm{Cl}_{2}$ & 10 & 60 & 90 \\
\hline 7 & $\mathrm{MeCO}_{2} \mathrm{Et}$ & 10 & 60 & 90 \\
\hline
\end{tabular}

Using the same mixture of solvents, $\mathrm{NH}_{4} \mathrm{Cl},{ }^{13} \mathrm{NH}_{4} \mathrm{~F}$, para-toluenesulfonic acid (PTSA), trichloroacetic acid, $\mathrm{HCl}$ and $\mathrm{HF}$ were compared to ABF (Scheme 2, Table 2). The quantitative yield of $\mathbf{3 a}$ obtained after 5 min at room temperature using $1 \mathrm{~mol} \%$ of $\mathrm{ABF}$ (Table 2, entry 1) was reproduced using $\mathrm{NH}_{4} \mathrm{Cl}$, but provided that $50 \mathrm{~mol} \%$ were employed (Table 2, entry 2). After the same reaction time, $\mathrm{NH}_{4} \mathrm{~F}$ (50 mol $\%$ ) afforded $\mathbf{3 a}$ in $92 \%$ yield (Table 2, entry 3 ). Among the catalysts capable of acting as Brönsted acids, HF proved the best to promote the formation of the quinoxaline derivative.

\begin{tabular}{lll}
$\begin{array}{l}\text { Table } 2 \\
\text { different catalysts (reaction time: } 5 \mathrm{~min})\end{array}$ & $\begin{array}{l}\text { Synthesis of } \mathbf{3 a} \text { in } 4: 1 \mathrm{MeOH}-\mathrm{H}_{2} \mathrm{O} \text { at } 20{ }^{\circ} \mathrm{C} \text { using } \\
\text { Entry }\end{array}$ & \\
\hline 1 & Catalyst (mol \%) & Yield (\%) \\
2 & $\mathrm{NH}_{4} \mathrm{HF}_{2}(1)$ & $>99$ \\
3 & $\mathrm{NH}_{4} \mathrm{Cl}(50)$ & $>99$ \\
4 & $\mathrm{NH}_{4} \mathrm{~F}(50)$ & 92 \\
5 & $\mathrm{PTSA}^{2}(1)$ & 90 \\
6 & $\mathrm{Cl}_{3} \mathrm{CCO}_{2} \mathrm{H}(1)$ & 83 \\
7 & $\mathrm{HCl}(1)$ & 88 \\
\hline
\end{tabular}

The optimized conditions in hands, we evaluated the scope of the reaction by testing different 1,2dicarbonyl compounds (Table 3). Benzil (2a), pyruvophenone (2b), 1,2-indanedione (2c), and even 1,2-butanedione $(\mathbf{2 d})$ reacted very easily with 1,2phenylenediamine (1a), affording after simple filtration the corresponding 2,3-disubstituted quinoxalines 3a-d in high yields (Table 3, entries 1-4). ABF proved for example a catalyst superior to gallium(III) triflate, which does not allow the formation of $\mathbf{3 d}$ when used in methanol at room temperature. ${ }^{14}$ Besides 1,2-diketones, ketoaldehydes were also involved in the reaction. Phenyl glyoxal (2e), 4-anisyl glyoxal (2f), 2-naphthyl glyoxal (2g), 2furyl glyoxal (2h) and 2-thienyl glyoxal (2i) led to the expected monosubstituted derivatives 3e-i, respectively, in high yields (Table 3, entries 5-9). Reacting benzyl (2a) with 2,3-pyridinediamine (1b) also furnished the expected 2,3-diphenyl derivative 4a satisfactorily (Table 3, entry 10).

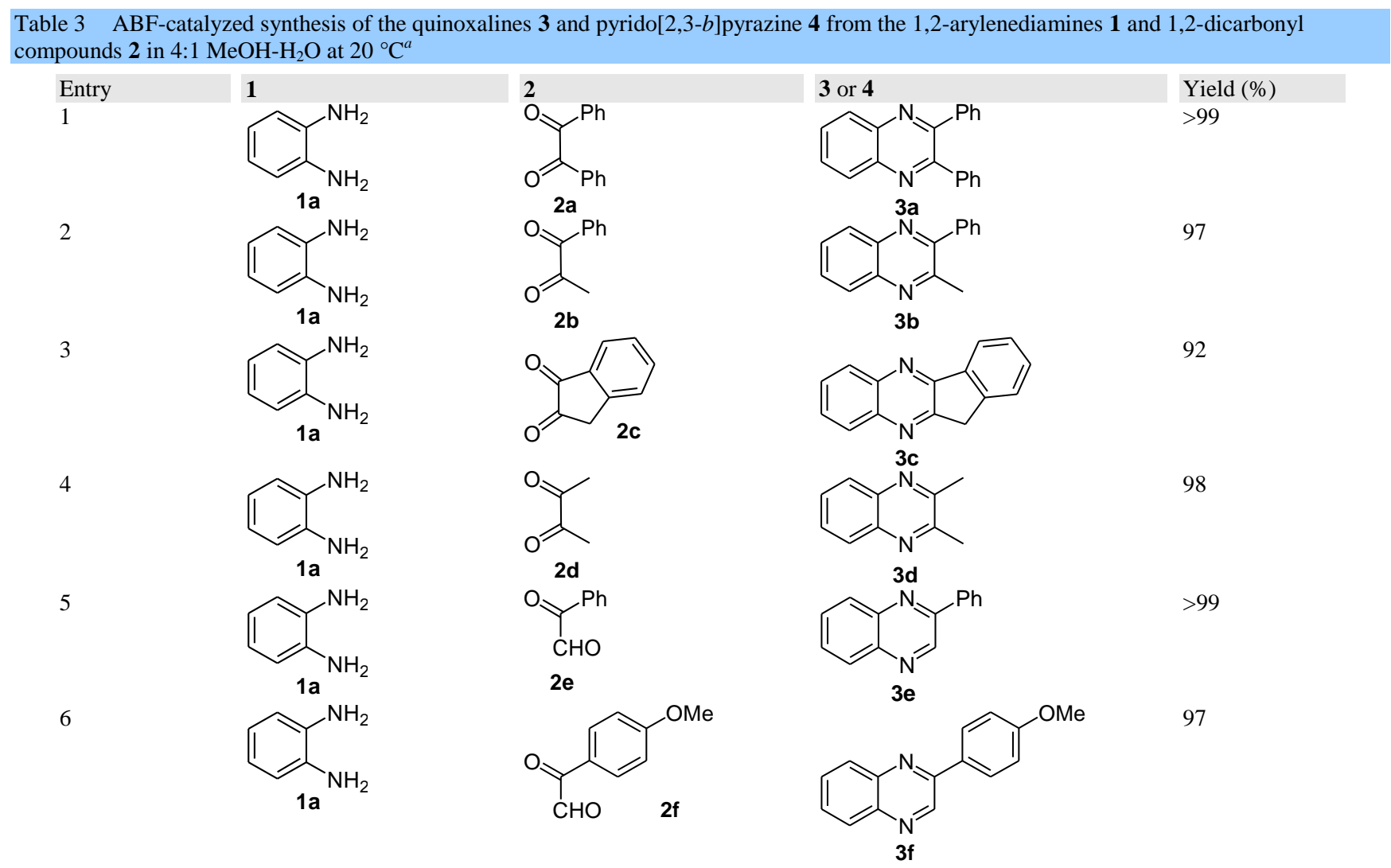


<smiles>Nc1ccccc1N</smiles>

8<smiles>Nc1ccccc1N</smiles>

9<smiles>Nc1ccccc1N</smiles>

10<smiles>Nc1cccnc1N</smiles><smiles>O=CC(=O)c1ccc2ccccc2c1</smiles><smiles>O=CC(=O)c1ccco1</smiles><smiles>O=CC(=O)c1cccs1</smiles><smiles>O=C(C(=O)c1ccccc1)c1ccccc1</smiles>

$2 a$<smiles>c1ccc2cc(-c3cnc4ccccc4n3)ccc2c1</smiles><smiles>c1coc(-c2cnc3ccccc3n2)c1</smiles>

$90^{b}$

${ }^{a}$ Reaction conditions: diamine ( $\left.1.0 \mathrm{mmol}\right)$, dicarbonyl compound used as hydrate (1.0 mmol), ABF (0.5 mol \%), $\mathrm{MeOH}(2 \mathrm{~mL}), \mathrm{H}_{2} \mathrm{O}$ $(0.5 \mathrm{~mL}), 15 \mathrm{~min}$, room temperature. ${ }^{b}$ Reaction performed overnight using $5 \mathrm{~mol} \% \mathrm{ABF}$.

Interestingly, a regioselectivity resulted from reactions between both unsymmetrical 1,2-dicarbonyl compounds and 1,2-arylenediamines (Table 4). So, when 3-methyl-1,2-phenylenediamine (1c) was reacted with phenyl glyoxal (2e), the regioisomer identified as 5e was isolated by column chromatography in $94 \%$ yield (Table 4 , entry 1). A similar result was noted by using 4-anisyl glyoxal (2f), 2-nitrophenyl glyoxal (2j), 2-naphthyl glyoxal (2g), 2-furyl glyoxal (2h) and 2-thienyl glyoxal (2i), to give as predominant isomer the compounds $\mathbf{5 f}, \mathbf{5 j}$, $\mathbf{5 g}, \mathbf{5 h}$ and $\mathbf{5 i}$, respectively (Table 4, entries $2-6$ ). The major disubstituted quinoxalines $\mathbf{5 e - j}$, as well as the minor disubstituted quinoxalines $\mathbf{5}$ 'g and $\mathbf{5}$ 'i, were unequivocally identified as by X-ray structure analysis (Figure 1). In a first approach, the regioselectivity observed could be rationalized by a favored reaction between the less congested amino group and the more reactive carbonyl function.

2,3-Pyridinediamine (1b), which possesses a more reactive amino group at $\mathrm{C} 3$, also furnished the expected monosubstituted pyrido[2,3-b]pyrazines $\mathbf{6 j}$, $\mathbf{6 h}$ and $\mathbf{6 i}$ by using 2-nitrophenyl glyoxal (2j), 2-furyl glyoxal (2h) and 2-thienyl glyoxal (2i), respectively (Table 4, entries 7-9, Figure 2). This demonstrates the potential extension of the reaction to other 1,2arylenediamines benefitting from different amine reactivities and/or steric hindrances.

Table 4 ABF-catalyzed synthesis of the quinoxalines 5 and pyrido[2,3- $b$ ]pyrazines $\mathbf{6}$ from both unsymmetrical 1,2-arylenediamines 1 and 1,2dicarbonyl compounds 2 in $4: 1 \mathrm{MeOH}-\mathrm{H}_{2} \mathrm{O}$ at $20^{\circ} \mathrm{C}^{a}$

Entry

1<smiles>Cc1cccc(N)c1N</smiles>

2<smiles>Cc1cccc(N)c1N</smiles>

3<smiles>Cc1cccc(N)c1N</smiles>

4<smiles>O=CC(=O)c1ccccc1</smiles>

$2 \mathrm{e}$<smiles>CCCCC(=O)c1ccc(OC)cc1</smiles><smiles>CC(=O)c1ccccc1[N+](=O)[O-]</smiles><smiles>O=CC(=O)c1ccc2ccccc2c1</smiles><smiles>Oc1cccc2ncc(-c3ccccc3)nc12</smiles>

$5 e$<smiles>COc1ccc(-c2cnc3cccc(C)c3n2)cc1</smiles><smiles>Cc1cccc2ncc(-c3ccccc3[N+](=O)[O-])nc12</smiles>

$5 \mathbf{j}$<smiles>Cc1cccc2ncc(-c3ccc4ccccc4c3)nc12</smiles>

Yield (\%)

$94^{b}$

$95^{b}$

$91^{c}$

$94^{b}$ 
5<smiles>Cc1cccc(N)c1N</smiles>

6<smiles>Cc1cccc(N)c1N</smiles>

7<smiles>Nc1cccnc1N</smiles>

1b

8<smiles>Nc1cccnc1N</smiles>

9<smiles>Nc1cccnc1N</smiles><smiles>Cc1cccc2nc(-c3ccc4ccccc4c3)cnc12</smiles><smiles>O=CC(=O)c1ccco1</smiles><smiles>Cc1cccc2c1nc(-c1ccco1)c[n+]2S</smiles><smiles>O=CC(=O)c1cccs1</smiles><smiles>Cc1cccc2nc(-c3cccs3)cnc12</smiles><smiles>O=CC(=O)c1ccccc1[N+](=O)[O-]</smiles><smiles>O=[N+]([O-])c1ccccc1-c1cnc2cccnc2n1</smiles>

6]<smiles>O=CC(=O)c1ccco1</smiles><smiles>c1coc(-c2cnc3cccnc3n2)c1</smiles><smiles>c1cnc2ncc(-c3ccsc3-c3cnc4cccnc4n3)nc2c1</smiles>

${ }^{a}$ Reaction conditions: diamine (1.0 mmol), dicarbonyl compound used as hydrate $(1.0 \mathrm{mmol}), \mathrm{ABF}(0.5 \mathrm{~mol} \%), \mathrm{MeOH}(2 \mathrm{~mL}), \mathrm{H}_{2} \mathrm{O}$ $(0.5 \mathrm{~mL}), 15 \mathrm{~min}$, room temperature. ${ }^{b}$ Major isomer isolated by silica gel chromatography. ${ }^{c}$ Only one regioisomer formed in this case. ${ }^{d}$ Minor isomer isolated by silica gel chromatography.
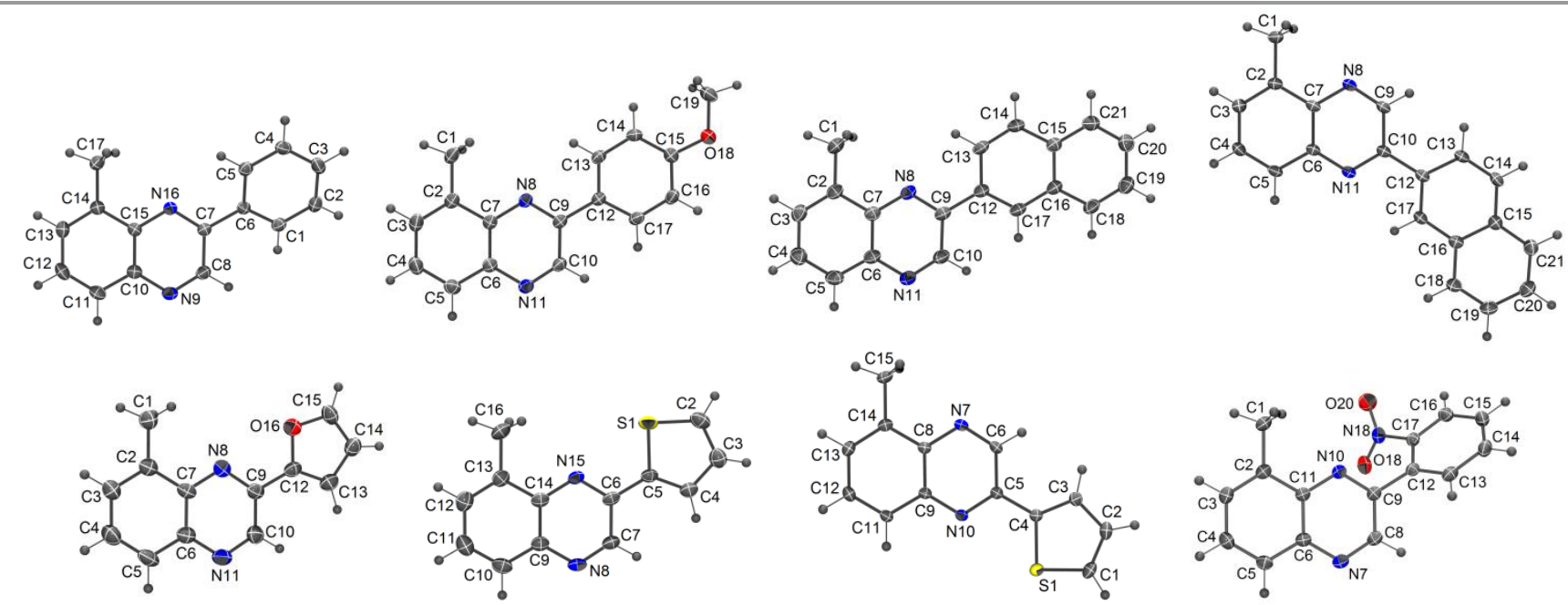

Figure 1 ORTEP diagram (50\% probability) of $\mathbf{5 e}, \mathbf{5 f}, \mathbf{5 g}, \mathbf{5}$ 'g, $\mathbf{5} \mathbf{h}, \mathbf{5 i}, \mathbf{5}$ 'i and $\mathbf{5 j}$

Thus, $\mathrm{ABF}$ gave $\mathbf{3 a}$ in a quantitative yield after a short reaction time. Even at a loading lower than $1 \mathrm{~mol} \%$, a rapid reaction was observed at room temperature. The derivatives were isolated in high purity after simple 
filtration. The reusability of the filtrate $A B F$ was evaluated using the optimized procedure. The filtrates could be recycled five times without noticeable change of the catalytic activity of ABF.

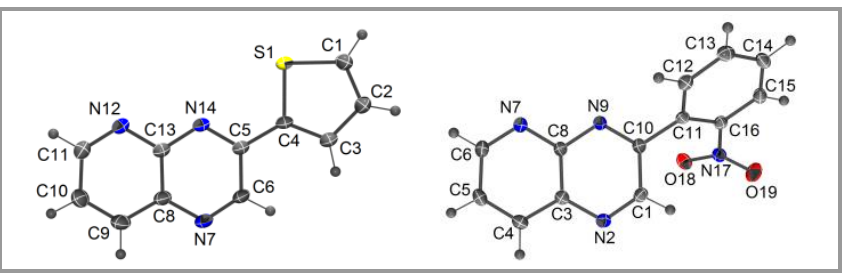

Figure 2 ORTEP diagram (50\% probability) of $\mathbf{6 i}$ and $\mathbf{6 j}$

\section{A DFT reactivity analysis of the ABF catalyzed condensation reactions.}

The ABF catalyzed condensation reaction of 1,2arylenediamines with 1,2-dicarbonyl compounds was analyzed using the reactivity indices defined within the conceptual DFT. ${ }^{15}$ In a polar protic solvent, ABF can be dissociated yielding different charged species. Consequently, three molecular complexes catalyzing the nucleophilic attack of 1,2-arylenediamines to dicarbonyl compounds were considered: i) in model I, namely $\mathbf{2 i}: \mathrm{ABF}$, an ammonium hydrogen atom of $\mathrm{ABF}$ molecular complex was hydrogen-bonded to the ketone oxygen atom; ii) in model II, namely $2 \mathbf{i}: \mathrm{NH} 4$, the ammonium cation $\mathrm{NH}_{4}{ }^{+}$was hydrogen-bonded to the ketone oxygen atom, and finally iii) in model III, namely $2 \mathbf{i}: \mathrm{H}$, a proton was bonded to the ketone oxygen atom (see Figure 3). Note that the molecular complex 2i:H would be considered as a Brönsted catalysis model. ${ }^{16}$ The values of global descriptors, namely, electronic chemical potential $\mu$, chemical hardness $\eta$, global electrophilicity $\omega$, and global nucleophilicity $N$ indices for some representative reagents involved in these condensation reactions are given in Table 5.

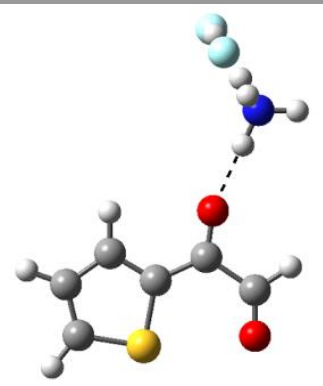

2i:ABF

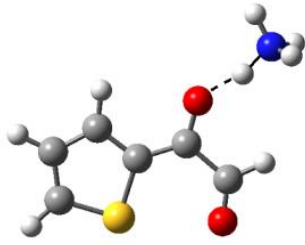

2i:NH4

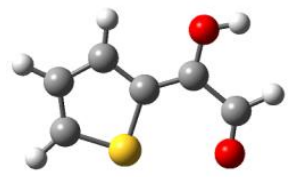

$2 \mathrm{i}: \mathrm{H}$

Figure 3 B3LYP/6-31G(d,p) structure of the molecular complexes $2 \mathbf{i}: \mathrm{ABF}, \mathbf{2 i} \mathrm{iHH} 4$ and $\mathbf{2 i}: \mathrm{H}$

Table 5 B3LYP/6-31G(d,p) electronic chemical potential $\mu$, chemical hardness $\eta$, global electrophilicity $\omega$, and global nucleophilicity $N$ indices, in $\mathrm{eV}$, of some representative reagents involved in the condensation reactions

$\begin{array}{lllll} & \mu & \eta & \omega & N \\ \mathbf{2 i}: \mathrm{H} & -10.35 & 3.61 & 14.87 & -3.04 \\ \mathbf{2 i}: \text { NH4 } & -8.54 & 3.67 & 9.92 & -1.26 \\ \mathbf{2 i}: \text { ABF } & -5.52 & 3.93 & 3.87 & 1.63 \\ \mathbf{2 i} & -4.94 & 4.06 & 3.01 & 2.15 \\ \mathbf{1 b} & -2.66 & 5.27 & 0.67 & 3.82 \\ \mathbf{1 c} & -2.19 & 5.58 & 0.43 & 4.14\end{array}$

The electrophilicity $\omega$ index $^{17}$ of the 1,2-dicarbonyl compound $\mathbf{2} \mathbf{i}$ is very high, $3.01 \mathrm{eV}$, being classified as a strong electrophile. ${ }^{18}$ Formation of a hydrogen bond between $\mathrm{ABF}$ and the ketone oxygen atom of $\mathbf{2 i}$ increases the electrophilicity $\omega$ index of complex 2i:ABF to $3.87 \mathrm{eV}^{19}$ A more drastic electrophilic activation is found when the $\mathrm{NH}_{4}{ }^{+}$cation is hydrogenbonded to the carbonyl oxygen atom in $2 \mathbf{i}: \mathrm{NH} 4, \boldsymbol{\omega}=$ $9.92 \mathrm{eV}$. Finally, protonation of the oxygen atom considerably increases the electrophilicity $\omega$ index of complex 2i:H to $14.87 \mathrm{eV}$. Clearly, both the ammonium cation and the proton are able to catalyze the addition reactions.

The 1,2-arylenediamines present a high nucleophilicity $N$ index, ${ }^{20} 3.82$ (1b) and 4.14 (1c) $\mathrm{eV}$, respectively, being classified as strong nucleophiles. ${ }^{21}$
Note that the tolyl derivative 1c is more nucleophilic than the pyridine one $\mathbf{1 b}$.

The high electrophilic character of complexes $2 \mathbf{i}: \mathrm{H}$ and 2i:NH4, together with the high nucleophilic character of 1c and $\mathbf{1 b}$, account for the feasibility of these condensation reactions which are initialized by the nucleophilic attack of one amine nitrogen atom of these 1,2-arylenediamine derivatives on the activated carbonyl carbon of complexes $\mathbf{2} \mathbf{i}: \mathbf{H}$ or $\mathbf{2 i}: \mathbf{N H} 4$.

The local electrophilicity $\omega_{\mathrm{k}}$ indices $^{22}$ in $\mathbf{2} \mathbf{i}, \mathbf{2} \mathbf{i}: \mathrm{ABF}$, $\mathbf{2 i}: \mathrm{NH} 4$ and $\mathbf{2 i}: \mathrm{H}$, and the local nucleophilicity $N_{\mathrm{k}}$ indices $^{23}$ in $\mathbf{1 c}$ and $\mathbf{1 b}$ were analyzed in order to explain the regioselectivity (see Table 6). The ketone $\mathrm{C} 2$ carbon of $\mathbf{2 i}, \omega_{\mathrm{C} 2}=0.53 \mathrm{eV}$, is slightly more electrophilically activated that the aldehyde $\mathrm{C} 1$ carbon, $\omega_{\mathrm{C} 1}=0.45 \mathrm{eV}$. Interestingly, formation of the 
hydrogen bond between $\mathrm{ABF}$ and the ketone oxygen atom of $2 \mathbf{i}$ does not only increase the global electrophilicity of $2 \mathbf{i}: \mathrm{ABF}$, but it also makes the reaction chemoselective since the ketone carbonyl carbon, $\omega_{\mathrm{C} 2}=0.90 \mathrm{eV}$, is twice more electrophilic that the aldehyde one, $\omega_{\mathrm{C} 1}=0.52 \mathrm{eV}$. A more noticeable local activation is found in complexes $2 \mathbf{i}: \mathrm{NH} 4$ and $\mathbf{2 i}: \mathrm{H}$ in which the carbonyl $\mathrm{C} 2$ carbon is strongly activated, the addition being completely chemoselective (see Table 6).

Table 6 Local electrophilicity $\omega_{\mathrm{Ck}}$ indices at the carbonyl carbon atoms of $\mathbf{2 i}, \mathbf{2 i}: \mathrm{ABF}, \mathbf{2 i}: \mathrm{NH} 4$ and $\mathbf{2 i}: \mathrm{H}$, and local nucleophilicity $N_{\mathrm{Nk}}$ indices at the nitrogen atoms of the 1,2-arylenediamines $\mathbf{1 b}$ and $\mathbf{1 c}$, in $\mathrm{eV}$

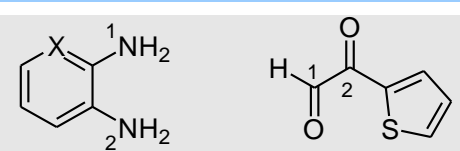

$\mathrm{X}=\mathrm{N}, \mathrm{CMe}$

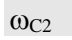

6.02

3.27

0.90

0.53

$\begin{array}{ll}0.85 & 0.86 \\ 0.96 & 0.75\end{array}$

Analysis of the local nucleophilicity $N_{\mathrm{k}}$ index at the pyridine derivative $\mathbf{1 b}$ indicates that there is not a clear differentiation between the two nitrogen atoms. However, when they are analyzed in the tolyl derivative 1c, the nitrogen $\mathrm{N} 1$ atom located in the ortho position to the methyl group is more nucleophilically activated than the nitrogen $\mathrm{N} 2$ atom.

This poor local nucleophilic discrimination between the two nitrogen atoms can be in relation with the total electron-density considered when computing the Parr functions. However, along the nucleophilic attack, only the non-bonding lone pairs of these nitrogen atoms participate in the addition. A natural bond orbital (NBO) analysis of the two 1,2-arylenediamines indicates that the lone pair of the $\mathrm{N} 2$ nitrogen atom is $3.07(\mathbf{1 b})$ and $4.57(\mathbf{1 c}) \mathrm{kcal} / \mathrm{mol}$ below in energy than the lone pair of the N1 nitrogen atom. Consequently, it is expected that along the nucleophilic attack of these 1,2-arylenediamines on the most electrophilic C2 carbon of $2 \mathbf{i}: \mathrm{NH} 4$ or $2 \mathbf{i}: \mathrm{H}$, the more energetic N1 lone pair will participate more efficiently.

Liquid chromatography separations were achieved on silica gel Merck-Geduran Si $60(63-200 \mu \mathrm{m})$. Nuclear Magnetic Resonance spectra were acquired using Bruker AC-300 spectrometer $(300 \mathrm{MHz}$ and $75 \mathrm{MHz}$ for ${ }^{1} \mathrm{H}$ and ${ }^{13} \mathrm{C}$ respectively). ${ }^{1} \mathrm{H}$ chemical shifts $(\delta)$ are given in ppm relative to the residual solvent peak, and ${ }^{13} \mathrm{C}$ chemical shifts relative to the central peak of the solvent signal. $^{24}$

Phenyl glyoxal (2e) is commercially available. 1,2Indanedione (2c) $){ }^{25}$ 4-anisyl glyoxal (2f), ${ }^{26}$ 2-naphthyl glyoxal (2g), ${ }^{27}$ 2-furyl glyoxal (2h) ${ }^{28} \quad$ 2-thienyl glyoxal (2i) $)^{29}$ and 2-nitrophenyl glyoxal $(\mathbf{2 j})^{30}$ were prepared according to literature references. ${ }^{27}$
In summary, we have developed a safe and economical process for the room temperature and catalytic synthesis of quinoxaline and pyrido[2,3$b]$ pyrazine derivatives from 1,2-arylenediamines and 1,2-dicarbonyl compounds. The reusability of the catalyst, easy handling (no glassware etching at this concentration and temperature), and commercial availability, together with the mild reaction conditions, the simple work-up procedure and the short reaction time in spite of low catalyst concentrations, are the strong practical points of the presented method.

The reactivity and regioselectivity observed in the course of reactions using both unsymmetrical 1,2dicarbonyl compound and 1,2-arylenediamine was rationalized in the light of theoretical studies based on the DFT global and local reactivity indices. While the global electrophilicity $\infty$ index explains correctly the electrophilic activation of the 1,2-dicarbonyl compound by formation of a hydrogen bond to the $\mathrm{ABF}$ catalyst, the local counterpart explains the local activation of the $\mathrm{C} 2$ carbonyl carbon atom.

$X$-ray Crystallography. The samples were studied with graphite monochromatized Mo-K $\alpha$ radiation $(\lambda=$ $0.71073 \AA$ ). The X-ray diffraction data were collected using APEXII, Bruker-AXS diffractometer at $T=$ 150(2) K. All structures were solved by direct methods using the SIR97 program, ${ }^{32}$ and then refined with full-matrix least-square methods based on $F^{2}$ $\left(\right.$ SHELX-97) ${ }^{33}$ with the aid of the WINGX program. ${ }^{34}$ All non-hydrogen atoms were refined with anisotropic atomic displacement parameters. $\mathrm{H}$ atoms were finally included in their calculated positions. Molecular diagrams were generated by ORTEP-3 (version 2.02). ${ }^{34}$ 
General procedure 1 for the synthesis of the quinoxalines 3 . The 1,2-arylenediamine $(1.0 \mathrm{mmol})$ was added to a stirred mixture of the 1,2-dicarbonyl compound $(1.0 \mathrm{mmol})$ in $\mathrm{H}_{2} \mathrm{O}(0.5 \mathrm{~mL})$ and $2.0 \mathrm{~mL}$ of $2.5 .10^{-3} \mathrm{~mol} \mathrm{~L}^{-1} \mathrm{NH}_{4} \mathrm{HF}_{2}(5.0 \mu \mathrm{mol})$ in $\mathrm{MeOH}$ at room temperature. After $15 \mathrm{~min}$ reaction time, the mixture was cooled using an ice bath. The solid was filtered, washed with water, and dried to afford the pure expected product.

2,3-Diphenylquinoxaline (3a) was prepared from 1,2-phenylenediamine (1a) and benzil (2a) according to the general procedure 1 in a quantitative yield $(0.28$ g) as a white powder: mp $128-130{ }^{\circ} \mathrm{C}$ (lit. ${ }^{35} 130-131$ $\left.{ }^{\circ} \mathrm{C}\right)$.

2-Methyl-3-phenylquinoxaline (3b) was prepared from 1,2-phenylenediamine (1a) and pyruvophenone (2b) according to the general procedure 1 in $97 \%$ yield $(0.21 \mathrm{~g})$ as a red powder: $\mathrm{mp} 58{ }^{\circ} \mathrm{C}$ (lit. ${ }^{36} 57-58$ $\left.{ }^{\circ} \mathrm{C}\right)$.

11H-Indeno[1,2-b]quinoxaline (3c) was prepared from 1,2-phenylenediamine (1a) and 1,2-indanedione (2c) according to the general procedure 1 in $92 \%$ yield $(0.20 \mathrm{~g})$ as a yellow powder. The analyses were found similar to those previously reported. ${ }^{9 \mathrm{~d}}$

2,3-Dimethylquinoxaline (3d) was prepared from 1,2-phenylenediamine (1a) and 1,2-butanedione (2d) according to the general procedure 1 in $98 \%$ yield $(0.16 \mathrm{~g})$ as a pale yellow powder: $\mathrm{mp} 106{ }^{\circ} \mathrm{C}$ (lit. ${ }^{37}$ 104-106 $\left.{ }^{\circ} \mathrm{C}\right)$.

2-Phenylquinoxaline (3e) was prepared from 1,2phenylenediamine (1a) and phenyl glyoxal (2e) according to the general procedure 1 in a quantitative yield $(0.21 \mathrm{~g})$ as a white powder: $\mathrm{mp} 78^{\circ} \mathrm{C}$ (lit. ${ }^{38} 78$ $\left.79^{\circ} \mathrm{C}\right)$.

2-(4-Methoxyphenyl)quinoxaline (3f) was prepared from 1,2-phenylenediamine (1a) and 4-anisyl glyoxal (2f) according to the general procedure 1 in $97 \%$ yield $(0.23 \mathrm{~g})$ as a white powder: $\mathrm{mp} 100-102{ }^{\circ} \mathrm{C}$ (lit. ${ }^{39} 100$ $\left.101{ }^{\circ} \mathrm{C}\right)$.

2-(2-Naphthyl)quinoxaline (3g) was prepared from 1,2-phenylenediamine (1a) and 2-naphthyl glyoxal (2g) according to the general procedure 1 in $98 \%$ yield $(0.25 \mathrm{~g})$ as a white powder: $\mathrm{mp} 140{ }^{\circ} \mathrm{C}$ (lit. ${ }^{40} 141-142$ $\left.{ }^{\circ} \mathrm{C}\right)$.

2-(2-Furyl)quinoxaline (3h) was prepared from 1,2phenylenediamine (1a) and 2-furyl glyoxal (2h) according to the general procedure 1 in $98 \%$ yield $(0.20 \mathrm{~g})$ as a beige powder: $\mathrm{mp} 102-104{ }^{\circ} \mathrm{C}$ (lit. ${ }^{41} 99-$ $\left.100^{\circ} \mathrm{C}\right)$.

2-(2-Thienyl)quinoxaline (3i) was prepared from 1,2phenylenediamine (1a) and 2-thienyl glyoxal (2i) according to the general procedure 1 in $94 \%$ yield $(0.20 \mathrm{~g})$ as a pale yellow powder: $\mathrm{mp} 120-122{ }^{\circ} \mathrm{C}$ (lit. ${ }^{42} 120-121^{\circ} \mathrm{C}$ ).

2,3-Diphenylpyrido[2,3-b]pyrazine (4a). 2,3Diaminopyridine (1) $1.0 \mathrm{mmol})$ was added to $2.0 \mathrm{~mL}$ of $2.5 .10^{-2} \mathrm{~mol} \mathrm{~L}^{-1} \mathrm{NH}_{4} \mathrm{HF}_{2}(50 \mu \mathrm{mol})$ in $\mathrm{MeOH}$ and benzil $(2 \mathbf{a}, 1.0 \mathrm{mmol})$ in $\mathrm{H}_{2} \mathrm{O}(0.5 \mathrm{~mL})$ at room temperature. The mixture was stirred overnight and cooled using an ice bath. The solid was filtered, washed with water, and dried to afford the pure expected product in $90 \%$ yield $(0.25 \mathrm{~g})$ as a pale yellow powder: mp $148^{\circ} \mathrm{C}$ (lit. ${ }^{35} 144-145^{\circ} \mathrm{C}$ ).

General procedure 2 for the synthesis of the quinoxalines 5. The 1,2-arylenediamine $(1.0 \mathrm{mmol})$ was added to a stirred mixture of the 1,2-dicarbonyl compound $(1.0 \mathrm{mmol})$ in $\mathrm{H}_{2} \mathrm{O}(0.5 \mathrm{~mL})$ and $2.0 \mathrm{~mL}$ of 2.5.10 mol L$^{-1} \mathrm{NH}_{4} \mathrm{HF}_{2}(5.0 \mu \mathrm{mol})$ in $\mathrm{MeOH}$ at room temperature. After $15 \mathrm{~min}$, the mixture was cooled using an ice bath. The solid was filtered, washed with water, dried and (except for the nitro compounds) chromatographed over silica gel (the eluent is given in the product description).

8-Methyl-2-phenylquinoxaline (5e) was prepared from 3-methyl-1,2-phenylenediamine (1c) and phenyl glyoxal (2e) according to the general procedure 2 in $94 \%$ yield $(0.21 \mathrm{~g})$ as a pale yellow powder: $R_{\mathrm{f}} 0.21$ (pentane:EtOAc 4:1); mp $104{ }^{\circ} \mathrm{C} ;{ }^{1} \mathrm{H}$ NMR $\left(\mathrm{CDCl}_{3}\right.$, $300 \mathrm{MHz}): \delta=2.88$ (s, 3H), 7.50-7.65 (m, 5H), 7.93$7.97(\mathrm{~m}, 1 \mathrm{H}), 8.23-8.28(\mathrm{~m}, 2 \mathrm{H}) ; 9.33(\mathrm{~s}, 1 \mathrm{H}) ;{ }^{13} \mathrm{C}$ NMR $\left(\mathrm{CDCl}_{3}, 75 \mathrm{MHz}\right): \delta=17.2,127.0,127.5$ (2C), 129.2 (2C), 129.4, 130.1, 130.3, 137.1, 138.1, 141.4, $141.7,142.6,150.3$. The spectral data are analogous to those described previously. ${ }^{43}$ Crystal data for 5e: $\mathrm{C}_{15} \mathrm{H}_{12} \mathrm{~N}_{2}, M_{\mathrm{r}}=220.26$, monoclinic, $C 2 / c, a=$ 25.6227(11), $b=3.8431(2), c=22.7091(13) \AA, \beta=$ 92.300(2) ${ }^{\circ}, V=2234.4(2) \AA^{3}, Z=8, \rho_{\mathrm{c}}=1.31 \mathrm{~g} \mathrm{~cm}^{-3}$, $\mu=0.078 \mathrm{~mm}^{-1}$ (a final refinement on $F^{2}$ with 2519 unique intensities and 155 parameters converged at $\mathrm{w} R\left(F^{2}\right)=0.1044(R(F)=0.0431)$ for 1989 observed reflections with $I>2 \sigma(I))$. The data were deposited to the Cambridge Crystallographic Data Centre (CCDC 887677). ${ }^{40}$

2-(4-Methoxyphenyl)-8-methylquinoxaline (5f) was prepared from 3-methyl-1,2-phenylenediamine (1c) and 4-anisyl glyoxal (2f) according to the general procedure 2 in $95 \%$ yield $(0.24 \mathrm{~g})$ as a pale yellow powder: $R_{\mathrm{f}} 0.50\left(\mathrm{CH}_{2} \mathrm{Cl}_{2}\right.$ :pentane: $\left.4: 1\right) ; \mathrm{mp} 96{ }^{\circ} \mathrm{C} ;{ }^{1} \mathrm{H}$ NMR $\left(\mathrm{CDCl}_{3}, 300 \mathrm{MHz}\right): \delta=2.84(\mathrm{~s}, 3 \mathrm{H}), 3.87(\mathrm{~s}$, $3 \mathrm{H}), 7.04(\mathrm{~d}, 2 \mathrm{H}, J=9.0), 7.56(\mathrm{~d}, 2 \mathrm{H}, J=5.9), 7.91$ (dd, $1 \mathrm{H}, J=5.9$ and 4.0), $8.19(\mathrm{~d}, 2 \mathrm{H}, J=9.0), 9.26$ $(\mathrm{s}, 1 \mathrm{H}) ;{ }^{13} \mathrm{C} \mathrm{NMR}\left(\mathrm{CDCl}_{3}, 75 \mathrm{MHz}\right): \delta=17.2,55.5$, 114.5 (2C), 126.9, 128.8, 128.9 (2C), 129.7, 130.1, 137.7, 141.3, 141.3, 142.3, 149.8, 161.4. Crystal data for 5f: $\mathrm{C}_{16} \mathrm{H}_{14} \mathrm{~N}_{2} \mathrm{O}, M_{\mathrm{r}}=250.29$, monoclinic, $C 2 / c, a=$ 24.4240(16), $b=3.9155(2), c=27.2910(15) \AA, \beta=$ 107.981(3) ${ }^{\circ}, V=2482.4(2) \AA^{3}, Z=8, \rho_{\mathrm{c}}=1.339 \mathrm{~g}$ $\mathrm{cm}^{-3}, \mu=0.085 \mathrm{~mm}^{-1}$ (a final refinement on $F^{2}$ with 2808 unique intensities and 174 parameters converged at $\mathrm{w} R\left(F^{2}\right)=0.1155(R(F)=0.0459)$ for 2176 observed reflections with $I>2 \sigma(I))$. The data were deposited to the Cambridge Crystallographic Data Centre (CCDC 1034992). ${ }^{40}$

8-Methyl-2-(2-nitrophenyl)quinoxaline (5j) was prepared from 3-methyl-1,2-phenylenediamine (1c) and 2-nitrophenyl glyoxal $\mathbf{( 2 \mathbf { j } )}$ according to the 
general procedure 2 in $91 \%$ yield $(0.25 \mathrm{~g})$ as a white powder: mp $128{ }^{\circ} \mathrm{C} ;{ }^{1} \mathrm{H} \mathrm{NMR}\left(\mathrm{CDCl}_{3}, 300 \mathrm{MHz}\right): \delta=$ $2.75(\mathrm{~s}, 3 \mathrm{H}), 7.62-7.84(\mathrm{~m}, 5 \mathrm{H}), 7.97-8.02(\mathrm{~m}, 2 \mathrm{H})$, $9.04(\mathrm{~s}, 1 \mathrm{H}) ;{ }^{13} \mathrm{C} \mathrm{NMR}\left(\mathrm{CDCl}_{3}, 75 \mathrm{MHz}\right): \delta=17.1$, $124.9,127.0,130.2,130.4,130.6,131.5,132.7,132.8$, 138.3, 141.0, 141.8, 143.4, 148.9, 149.6. Crystal data for 5j: $\mathrm{C}_{15} \mathrm{H}_{11} \mathrm{~N}_{3} \mathrm{O}_{2}, M_{\mathrm{r}}=265.27$, monoclinic, $P 2_{1} / n, a$ $=7.7038(3), b=13.4722(6), c=12.1711(6) \AA, \beta=$ 96.793(2) ${ }^{\circ}, V=1254.34(10) \AA^{3}, Z=4, \rho_{\mathrm{c}}=1.405 \mathrm{~g}$ $\mathrm{cm}^{-3}, \mu=0.097 \mathrm{~mm}^{-1}$ (a final refinement on $F^{2}$ with 2861 unique intensities and 182 parameters converged at $\mathrm{w} R\left(F^{2}\right)=0.1018(R(F)=0.0385)$ for 2416 observed reflections with $I>2 \sigma(I))$. The data were deposited to the Cambridge Crystallographic Data Centre (CCDC 1034993).

8-Methyl-2-(2-naphthyl)quinoxaline (5g) was prepared from 3-methyl-1,2-phenylenediamine (1c) and 2-naphthyl glyoxal (2g) according to the general procedure 2 in $94 \%$ yield $(0.25 \mathrm{~g})$ as a pale yellow powder: $R_{\mathrm{f}} 0.37\left(\mathrm{CH}_{2} \mathrm{Cl}_{2}\right.$ :pentane 95:5); mp 148-150 ${ }^{\circ} \mathrm{C}$; ${ }^{1} \mathrm{H} \mathrm{NMR}\left(\mathrm{CDCl}_{3}, 300 \mathrm{MHz}\right): \delta=2.93(\mathrm{~s}, 3 \mathrm{H})$, 7.55-7.59 (m, 2H), 7.63-7.66 (m, 2H), 7.90-8.05 (m, 4H), $8.46(\mathrm{dd}, 1 \mathrm{H}, J=8.4$ and 1.8$), 8.69(\mathrm{~d}, 1 \mathrm{H}, J=$ 1.2), $9.50(\mathrm{~s}, 1 \mathrm{H}) ;{ }^{13} \mathrm{C} \mathrm{NMR}\left(\mathrm{CDCl}_{3}, 75 \mathrm{MHz}\right): \delta=$ $17.3,124.6,126.6,126.9,127.2,127.2,127.8,128.9$, 129.0, 129.4, 130.3, 133.4, 134.1, 134.4, 138.0, 141.4, 141.6, 142.7, 150.0. Crystal data for 5g: $\mathrm{C}_{19} \mathrm{H}_{14} \mathrm{~N}_{2}, M_{\mathrm{r}}$ $=270.32$, monoclinic, $P 2_{1} / n, a=14.4579(13), b=$ 4.6502(4), $c=20.8516(17) \AA, \beta=103.783(3){ }^{\circ}, V=$ $1361.5(2) \AA^{3}, Z=4, \rho_{\mathrm{c}}=1.319 \mathrm{~g} \mathrm{~cm}^{-3}, \mu=0.078$ $\mathrm{mm}^{-1}$ (a final refinement on $F^{2}$ with 3105 unique intensities and 191 parameters converged at $\mathrm{w} R\left(F^{2}\right)=$ $0.1334(R(F)=0.0542)$ for 1796 observed reflections with $I>2 \sigma(I))$. The data were deposited to the Cambridge Crystallographic Data Centre (CCDC 1034994). ${ }^{40}$ 5-Methyl-2-(2-naphthyl)quinoxaline (5'g) was similarly isolated in $5 \%$ yield $(13 \mathrm{mg})$ as a pale yellow powder and identified unambiguously by X-ray diffraction; $R_{\mathrm{f}} 0.51\left(\mathrm{CH}_{2} \mathrm{Cl}_{2}\right.$ :pentane 95:5); mp $154{ }^{\circ} \mathrm{C}$. Crystal data for 5'g: $\mathrm{C}_{19} \mathrm{H}_{14} \mathrm{~N}_{2}, M_{\mathrm{r}}=270.32$, monoclinic, $P 2_{1} / c, a=12.7711(10), b=4.4124(3), c=$ 23.9462(16) $\AA, \beta=95.816(3)^{\circ}, V=1342.45(17) \AA^{3}$, $Z=4, \rho_{\mathrm{c}}=1.337 \mathrm{~g} \mathrm{~cm}^{-3}, \mu=0.079 \mathrm{~mm}^{-1}$ (a final refinement on $F^{2}$ with 3068 unique intensities and 191 parameters converged at $\mathrm{w} R\left(F^{2}\right)=0.112(R(F)=$ 0.0418 ) for 2388 observed reflections with $I>2 \sigma(I))$. The data were deposited to the Cambridge Crystallographic Data Centre (CCDC 1034995). ${ }^{40}$

2-(2-Furyl)-8-methylquinoxaline (5h) was prepared from 3-methyl-1,2-phenylenediamine (1c) and 2-furyl glyoxal (2h) according to the general procedure 2 in $95 \%$ yield $(0.20 \mathrm{~g})$ as a beige powder: $R_{\mathrm{f}} 0.21$ $\left(\mathrm{CH}_{2} \mathrm{Cl}_{2}\right.$ :pentane 9:1); mp 70-72 ${ }^{\circ} \mathrm{C} ;{ }^{1} \mathrm{H} \mathrm{NMR}\left(\mathrm{CDCl}_{3}\right.$, $300 \mathrm{MHz}): \delta=2.81(\mathrm{~s}, 3 \mathrm{H}), 6.62(\mathrm{dd}, 1 \mathrm{H}, J=3.5$ and 1.8), $7.33(\mathrm{dd}, 1 \mathrm{H}, J=3.5$ and 0.8$), 7.56-7.59(\mathrm{~m}$, 2H), $7.66(\mathrm{dd}, 1 \mathrm{H}, J=1.8$ and 0.8$), 7.89(\mathrm{dd}, 1 \mathrm{H}, J=$ 5.4 and 4.5$), 9.25(\mathrm{~s}, 1 \mathrm{H}) ;{ }^{13} \mathrm{C} \mathrm{NMR}\left(\mathrm{CDCl}_{3}, 75\right.$ $\mathrm{MHz}): \delta=17.0,111.2,112.4,127.0,128.9,130.2$, 137.4, 141.1, 141.3, 141.3, 142.6, 144.6, 152.2. Crystal data for 5h: $2\left(\mathrm{C}_{13} \mathrm{H}_{10} \mathrm{~N}_{2} \mathrm{O}\right), M_{\mathrm{r}}=420.46$, monoclinic, $P 2_{1} / c, a=17.698(3), b=4.7568(7), c=$ 24.587(4) $\AA, \beta=92.295(6)^{\circ}, V=2068.2(6) \AA^{3}, Z=4$, $\rho_{\mathrm{c}}=1.35 \mathrm{~g} \mathrm{~cm}^{-3}, \mu=0.088 \mathrm{~mm}^{-1}$ (a final refinement on $F^{2}$ with 4713 unique intensities and 292 parameters converged at $\mathrm{w} R\left(F^{2}\right)=0.1677(R(F)=0.0778)$ for 1926 observed reflections with $I>2 \sigma(I))$. The data were deposited to the Cambridge Crystallographic Data Centre (CCDC 901747). ${ }^{40}$

8-Methyl-2-(2-thienyl)quinoxaline (5i) was prepared from 3-methyl-1,2-phenylenediamine (1b) and 2thienyl glyoxal (2i) according to the general procedure 2 in $95 \%$ yield $(0.22 \mathrm{~g})$ as a pale yellow powder: $R_{\mathrm{f}}$ $0.26\left(\mathrm{CH}_{2} \mathrm{Cl}_{2}\right.$ :pentane 9:1); mp $120{ }^{\circ} \mathrm{C} ;{ }^{1} \mathrm{H}$ NMR $\left(\mathrm{CDCl}_{3}, 300 \mathrm{MHz}\right): \delta=2.81(\mathrm{~s}, 3 \mathrm{H}), 7.18(\mathrm{dd}, 1 \mathrm{H}, J=$ 5.0 and 3.7), $7.51(\mathrm{dd}, 1 \mathrm{H}, J=5.0$ and 1.1$), 7.52-7.58$ $(\mathrm{m}, 2 \mathrm{H}), 7.83(\mathrm{dd}, 1 \mathrm{H}, J=3.7$ and 1.1), 7.86-7.90 (m, $1 \mathrm{H}), 9.19(\mathrm{~s}, 1 \mathrm{H}) ;{ }^{13} \mathrm{C} \mathrm{NMR}\left(\mathrm{CDCl}_{3}, 75 \mathrm{MHz}\right): \delta=$ $17.0,126.6,127.0,128.5,129.0,129.7,130.5,137.6$, 141.2, 141.4, 141.5, 143.0, 146.2. Crystal data for 5i: $\mathrm{C}_{13} \mathrm{H}_{10} \mathrm{~N}_{2} \mathrm{~S}, M_{\mathrm{r}}=226.29$, monoclinic, $P 2_{1} / c, a=$ 12.868(2), $b=4.5228(8), c=18.899(3) \AA, \beta=$ $92.293(6)^{\circ}, V=1099.0(3) \AA^{3}, Z=4, \rho_{\mathrm{c}}=1.368$ $\mathrm{g} \mathrm{cm}^{-3}, \mu=0.265 \mathrm{~mm}^{-1}$ (a final refinement on $F^{2}$ with 2496 unique intensities and 146 parameters converged at $\mathrm{w} R\left(F^{2}\right)=0.1249(R(F)=0.0535)$ for 1579 observed reflections with $I>2 \sigma(I))$. The data were deposited to the Cambridge Crystallographic Data Centre (CCDC 887678). ${ }^{40}$ 5-Methyl-2-(2-thienyl)quinoxaline (5'i) was similarly isolated in $5 \%$ yield $(11 \mathrm{mg})$ as a pale yellow powder and identified unambiguously by $\mathrm{X}$ ray diffraction: $R_{\mathrm{f}} 0.40\left(\mathrm{CH}_{2} \mathrm{Cl}_{2}\right.$ :pentane 9:1); mp 178$180{ }^{\circ} \mathrm{C}$. Crystal data for $\mathbf{5}^{\prime} \mathbf{i}: \mathrm{C}_{13} \mathrm{H}_{10} \mathrm{~N}_{2} \mathrm{~S}, M_{\mathrm{r}}=226.29$, monoclinic, $P 2_{1} / c, a=12.4419(6), b=4.7272(2), c=$ 18.1617(9) $\AA, \beta=98.448(2)^{\circ}, V=1056.60(9) \AA^{3}, Z=$ 4, $\rho_{\mathrm{c}}=1.423 \mathrm{~g} \mathrm{~cm}^{-3}, \mu=0.275 \mathrm{~mm}^{-1}$ (a final refinement on $F^{2}$ with 2418 unique intensities and 146 parameters converged at $\mathrm{w} R\left(F^{2}\right)=0.0936(R(F)=$ 0.0352 ) for 2126 observed reflections with $I>2 \sigma(I))$. The data were deposited to the Cambridge Crystallographic Data Centre (CCDC 887679). ${ }^{40}$

3-(2-(2-Nitrophenyl))pyrido[2,3-b]pyrazine (6j) was prepared from 2,3-diaminopyridine (1c) and 2nitrophenyl glyoxal $(\mathbf{2} \mathbf{j})$ according to the general procedure 2 in $90 \%$ yield $(0.23 \mathrm{~g})$ as a pale yellow powder: mp $188{ }^{\circ} \mathrm{C} ;{ }^{1} \mathrm{H}$ NMR $\left(\mathrm{CDCl}_{3}, 300 \mathrm{MHz}\right): \delta=$ 7.69-7.85 (m, 4H), $8.21(\mathrm{~d}, 1 \mathrm{H}, J=7.8), 8.55(\mathrm{dd}, 1 \mathrm{H}$, $J=8.1$ and 1.8), $9.00(\mathrm{~s}, 1 \mathrm{H}), 9.23(\mathrm{dd}, 1 \mathrm{H}, J=4.2$ and 1.8$) ;{ }^{13} \mathrm{C} \mathrm{NMR}\left(\mathrm{CDCl}_{3}, 75 \mathrm{MHz}\right): \delta=125.1$, $125.7,130.9,132.5,132.6,133.8,136.9,138.5,145.9$, 148.3, 150.5, 154.7, 154.8. Crystal data for $\mathbf{6 j}$ : $\mathrm{C}_{13} \mathrm{H}_{8} \mathrm{~N}_{4} \mathrm{O}_{2}, M_{\mathrm{r}}=252.23$, triclinic, $P-1, a=7.4757(4)$, $b=8.1279(5), c=9.8407(6) \AA, \alpha=107.383(2), \beta=$ 101.006(2), $\gamma=94.012(2)^{\circ}, V=554.96(6) \AA^{3}, Z=2$, $\rho_{\mathrm{c}}=1.509 \mathrm{~g} \mathrm{~cm}^{-3}, \mu=0.107 \mathrm{~mm}^{-1}$ (a final refinement on $F^{2}$ with 2515 unique intensities and 172 parameters converged at $\mathrm{w} R\left(F^{2}\right)=0.0987(R(F)=0.0390)$ for 2105 observed reflections with $I>2 \sigma(I))$. The data were deposited to the Cambridge Crystallographic Data Centre (CCDC 1034996). ${ }^{40}$ 
3-(2-Furyl)pyrido[2,3-b]pyrazine (6h) was prepared from 2,3-diaminopyridine (1c) and 2-furyl glyoxal (2h) according to the general procedure 2 in $93 \%$ yield $(0.18 \mathrm{~g})$ as a beige solid: $R_{\mathrm{f}} 0.30\left(\mathrm{CH}_{2} \mathrm{Cl}_{2}:\right.$ EtOAc 4:1); mp $132{ }^{\circ} \mathrm{C}$; ${ }^{1} \mathrm{H}$ NMR $\left(\mathrm{CDCl}_{3}, 300 \mathrm{MHz}\right): \delta=$ 6.67 (dd, $1 \mathrm{H}, J=3.6$ and 1.8), 7.59 (dd, $1 \mathrm{H}, J=3.6$ and 0.9$), 7.66(\mathrm{dd}, 1 \mathrm{H}, J=8.4$ and 4.5$), 7.72(\mathrm{dd}, 1 \mathrm{H}$, $J=1.8$ and 0.9$), 8.43(\mathrm{dd}, 1 \mathrm{H}, J=8.4$ and 2.1$), 9.15$ (dd, $1 \mathrm{H}, J=4.2$ and 2.1$), 9.40(\mathrm{~s}, 1 \mathrm{H}) ;{ }^{13} \mathrm{C} \mathrm{NMR}$ $\left(\mathrm{CDCl}_{3}, 75 \mathrm{MHz}\right): \delta=113.1,114.0,124.5,136.6$, 138.2, 143.1, 145.7, 146.6, 150.8, 151.3, 154.6.

3-(2-Thienyl)pyrido[2,3-b]pyrazine (6i) was prepared from 2,3-diaminopyridine (1c) and 2-thienyl glyoxal (2i) according to the general procedure 2 in $95 \%$ yield $(0.20 \mathrm{~g})$ as a pale yellow powder. The analyses were found similar to those previously reported. ${ }^{9 \mathrm{~d}}$ Crystal data for $6 \mathbf{6}: \mathrm{C}_{11} \mathrm{H}_{7} \mathrm{~N}_{3} \mathrm{~S}, M_{\mathrm{r}}=213.26$, monoclinic, $P 2_{1} / c, a=7.0026(3), b=13.0291(6), c=$ $11.0955(4) \AA, \beta=101.885(2)^{\circ}, V=990.62(7) \AA^{3}, Z=$ $4, \rho_{\mathrm{c}}=1.43 \mathrm{~g} \mathrm{~cm}^{-3}, \mu=0.291 \mathrm{~mm}^{-1}$ (a final refinement on $F^{2}$ with 2258 unique intensities and 136 parameters converged at $\mathrm{w} R\left(F^{2}\right)=0.0929(R(F)=0.0356)$ for 1945 observed reflections with $I>2 \sigma(I))$. The data were deposited to the Cambridge Crystallographic Data Centre (CCDC 887680). ${ }^{40}$ 2-(2Thienyl)pyrido[2,3-b]pyrazine (6'i) was similarly isolated in $5 \%$ yield $(11 \mathrm{mg})$ as a pale yellow powder. The analyses were found similar to those previously reported. $^{9 \mathrm{~d}}$

DFT computations were carried out using the $\mathrm{B} 3 \mathrm{LYP}^{45}$ functional, together with the standard 6$31 \mathrm{G}(\mathrm{d}, \mathrm{p})$ basis set. ${ }^{46}$ The electronic structures of the TSs were analysed by the natural bond orbital (NBO) method. ${ }^{47}$ The global electrophilicity index ${ }^{17} \omega$, is given by the following expression, $\omega=\left(\mu^{2} / 2 \eta\right)$, based on the electronic chemical potential $\mu$ and the chemical hardness $\eta$. Both quantities may be approached in terms of the one-electron energies of the frontier molecular orbital HOMO and LUMO, $\varepsilon_{\mathrm{H}}$ and $\varepsilon_{\mathrm{L}}$, as $\mu \approx\left(\varepsilon_{\mathrm{H}}+\varepsilon_{\mathrm{L}}\right) / 2$ and $\eta \approx\left(\varepsilon_{\mathrm{L}}-\varepsilon_{\mathrm{H}}\right)$, respectively. ${ }^{48}$ The global nucleophilicity index,${ }^{20} N$, based on the HOMO energies obtained within the Kohn-Sham scheme, ${ }^{49}$ is defined as $N=\mathrm{E}_{\text {Hомо }}(\mathrm{Nu})$ $\mathrm{E}_{\text {номо }}(\mathrm{TCE})$. This relative nucleophilicity index refers to tetracyanoethylene (TCE). The local electrophilicity $\omega_{\mathrm{k}}$ indices $^{22}$ and local nucleophilicity $N_{\mathrm{l}}$, indices ${ }^{23}$ were computed by using the electrophilic $P_{k}^{+}$and nucleophilic $P_{k}^{-}$Parr functions. ${ }^{50}$ All computations were carried out with the Gaussian 09 suite of programs. ${ }^{51}$

Supporting Information for this article (NMR spectra of the compounds $3 \mathbf{c}, \mathbf{5 e}, \mathbf{5 f}, \mathbf{5 j}, \mathbf{5 g}, \mathbf{5 h}, \mathbf{5 i}, \mathbf{6 j}$, $\mathbf{6 h}$ and $\mathbf{6 i}$ ) is available online at http://www.thiemeconnect.com/products/ejournals/journal/10.1055/s00000084 .

\section{Acknowledgment}

FM thanks the Institut Universitaire de France and Rennes Métropole. All the authors acknowledge Université de Rennes
1 and CNRS. They also thank Madani Hedidi for his contribution to the study.

\section{References}

(1) Ajani, O. O. Eur. J. Med. Chem. 2014, 85, 688.

(2) Sonawane, N. D.; Rangnekar, D. W. J. Heterocycl. Chem. 2002, 39, 303.

(3) Thomas, K. R. J.; Velusamy, M.; Lin, J. T.; Chuen, C.H.; Tao, Y.-T. Chem. Mater. 2005, 17, 1860.

(4) Dailey, S.; Feast, W. J.; Peace, R. J.; Sage, I. C.; Till, S.; Wood, E. L. J. Mater. Chem. 2001, 11, 2238.

(5) Brown, D. J. Chemistry of Heterocyclic Compounds (Hoboken, NJ, United States), Quinoxalines, Supplement 2; Eds.: Taylor, E. C.; Wipf, P.; John Wiley \& Sons: New Jersey, 2004.

(6) (a) Saifina, D. F.; Mamedov, V. A. Russ. Chem. Rev. 2010, 79, 351. (b) Mamedov, V. A.; Zhukova, N. A. Prog. Heterocycl. Chem. 2012, 24, 55.

(7) Nageswar, Y. V. D.; Reddy, K. H. V.; Ramesh, K.; Murthy, S. N. Org. Prep. Proced. Int. 2013, 45, 1.

(8) Wang, S.; Miller, W.; Milton, J.; Vicker, N.; Stewart, A.; Charlton, P.; Mistry, P.; Hardick, D.; Denny, W. A. Bioorg. Med. Chem. Lett. 2002, 12, 415.

(9) (a) Darabi, H. R.; Aghapoor, K.; Mohsenzadeh, F.; Jalali, M. R.; Talebian, S.; Ebadi-Nia, L.; Khatamifar, E.; Aghaee, A. Bull. Korean Chem. Soc. 2011, 32, 213. (b) Khalafy, J.; Marjani, A. P.; Haghipour, M. Curr. Chem. Lett. 2013, 2, 21. (c) Aghapoor, K.; Mohsenzadeh, F.; Shakeri, A.; Darabi, H. R.; Ghassemzadeh, M.; Neumuller, B. J. Organomet. Chem. 2013, 743, 170. (d) Lassagne, F.; Chevallier, F.; Mongin, F. Synth. Commun. 2014, 44, 141 .

(10) (a) Camps, F.; Chamorro, E.; Gasol, V.; Guerrero, A. J. Org. Chem. 1989, 54, 4294. (b) Kim, K.-Y.; Kim, B. C.; Lee, H. B.; Shin, H. J. Org. Chem. 2008, 73, 8106.

(11) Ooi, T.; Doda, K.; Maruoka, K. J. Am. Chem. Soc. 2003, 125, 2054.

(12) Lu, H.; Zhang, F.-M.; Pan, J.-L.; Chen, T.; Li, Y.-F. J. Org. Chem. 2014, 79, 546.

(13) Darabi, H. R.; Tahoori, F.; Aghapoor, K.; Taala, F.; Mohsenzadeh, F. J. Braz. Chem. Soc. 2008, 19, 1646.

(14) Cai, J.-J.; Zou, J.-P.; Pan, X.-Q.; Zhang, W. Tetrahedron Lett. 2008, 49, 7386.

(15) (a) Geerlings, P.; De Proft, F.; Langenaeker, W. Chem. Rev. 2003, 103, 1793. (b) Ess, D. H.; Jones, G. O.; Houk, K. N. Adv. Synth. Catal. 2006, 348, 2337.

(16) Domingo, L. R.; Oliva, M.; Andrés, J. J. Org. Chem. 2001, 66, 6151.

(17) Parr, R. G.; von Szentpaly, L.; Liu, S. J. Am. Chem. Soc. 1999, 121, 1922.

(18) Domingo, L. R.; Aurell, M. J.; Pérez, P.; Contreras, R. Tetrahedron 2002, 58, 4417.

(19) Domingo, L. R.; Andrés, J. J. Org. Chem. 2003, 68, 8662.

(20) Domingo, L. R.; Chamorro, E.; Pérez, P. J. Org. Chem. 2008, 73, 4615.

(21) Jaramillo, P.; Domingo, L. R.; Chamorro, E.; Pérez, P. J. Mol. Struct.: THEOCHEM 2008, 865, 68.

(22) Domingo, L. R.; Aurell, M. J.; Pérez, P.; Contreras, R. J. Phys. Chem. A 2002, 106, 6871.

(23) Pérez, P.; Domingo, L. R.; Duque-Noreña, M.; Chamorro, E. J. Mol. Struct.: THEOCHEM 2009, 895, 86.

(24) Gottlieb, H. E.; Kotlyar, V.; Nudelman, A. J. Org. Chem. 1997, 62, 7512.

(25) Hauze, D. B.; Petrovskaia, O.; Taylor, B.; Joullie, M. M.; Ramotowski, R.; Cantu, A. A. J. Forensic Sci. 1998, 43,744 . 
(26) Batchu, H.; Batra, S. Eur. J. Org. Chem. 2012, 2935.

(27) Wang, P.; Tao, W.-J.; Sun, X.-L.; Liao, S.; Tang, Y. J. Am. Chem. Soc. 2013, 135, 16849.

(28) Kipnis, F.; Ornfelt, J. J. Am. Chem. Soc. 1948, 70, 3948

(29) Kipnis, F.; Ornfelt, J. J. Am. Chem. Soc. 1946, 68, 2734.

(30) Sato, T.; Ohto, M. Bull. Chem. Soc. Jpn. 1955, 28, 480.

(31) Vogel, A. I.; Tatchell, A. R.; Furnis, B. S.; Hannaford, A. J.; Smith, P. W. G. Vogel's Textbook of Practical Organic Chemistry, 5th ed.; ELBS Longman: Singapore, 1991; p. 1955.

(32) Altomare, A.; Burla, M. C.; Camalli, M.; Cascarano, G. L.; Giacovazzo, C.; Guagliardi, A.; Moliterni, A. G. G.; Polidori, G.; Spagna, R. J. Appl. Crystallogr. 1999, 32, 115.

(33) Sheldrick, G. M. Acta Crystallogr., Sect. A 2008, A64, 112.

(34) Farrugia, L. J. J. Appl. Crystallogr. 2012, 45, 849.

(35) Nandi, G. C.; Samai, S.; Kumar, R.; Singh, M. S. Synth. Commun. 2011, 41, 417.

(36) Raju, B. C.; Theja, N. D.; Kumar, J. A. Synth. Commun. 2009, 39, 175.

(37) Giordano, C.; Belli, A.; Casagrande, F.; Guglielmetti, G.; Citterio, A. J. Org. Chem. 1981, 46, 3149.

(38) Tan, J.; Tang, W.; Sun, Y.; Jiang, Z.; Chen, F.; Xu, L.; Fan, Q.; Xiao, J. Tetrahedron 2011, 67, 6206.

(39) Wunderlich, S. H.; Rohbogner, C. J.; Unsinn, A.; Knochel, P. Org. Process Res. Dev. 2010, 14, 339.

(40) Wu, F.-W.; Hou, R.-S.; Wang, H.-M.; Kang, I.-J.; Chen, L.-C. Heterocycles 2011, 83, 2313.

(41) Lin, P.-Y.; Hou, R.-S.; Wang, H.-M.; Kang, I.-J.; Chen, L.-C. J. Chin. Chem. Soc. 2009, 56, 683.

(42) Kauffmann, T.; Ghanem, M.; Otter, R. Chem. Ber. 1982, $115,459$.

(43) Nguyen, T. B.; Retailleau, P.; Al-Mourabit, A. Org. Lett. 2013, 15, 5238 .

(44) More detailed information can be obtained free of charge from The Cambridge Crystallographic Data Centre via www.ccdc.cam.ac.uk/data_request/cif.

(45) (a) Lee, C.; Yang, W.; Parr, R. G. Phys. Rev. B 1988, 37, 785. (b) Becke, A. D. J. Chem. Phys. 1993, 98, 5648.

(46) Hehre, W. J.; Radom, L.; Schleyer, P. v. R.; Pople, J. A., Ab initio Molecular Orbital Theory; Wiley: New York, 1986.

(47) (a) Reed, A. E.; Weinstock, R. B.; Weinhold, F. J. Chem. Phys. 1985, 83, 735. (b) Reed, A. E.; Curtiss, L. A.; Weinhold, F. Chem. Rev. 1988, 88, 899.

(48) (a) Parr, R. G.; Pearson, R. G. J. Am. Chem. Soc. 1983, 105, 7512. (b) Parr, R. G.; Yang, W., Density Functional Theory of Atoms and Molecules; Oxford University Press: New York, 1989.

(49) Kohn, W.; Sham, L. J. Phys. Rev. A 1965, 140, 1133.

(50) Domingo, L. R.; Pérez, P.; Sáez, J. A. RSC Adv. 2013, 3, 1486.

(51) Frisch, M. J.; Trucks, G.W.; Schlegel, H. B.; Scuseria, G. E.; Robb, M. A.; Cheeseman, J. R.; Scalmani, G.; Barone, V.; Mennucci, B.; Petersson, G. A.; Nakatsuji, H.; Caricato, M.; Li, X.; Hratchian, H. P.; Izmaylov, A. F.; Bloino, J.; Zheng, G.; Sonnenberg, J. L.; Hada, M.; Ehara, M.; Toyota, K.; Fukuda, R.; Hasegawa, J.; Ishida, M.; Nakajima, T.; Honda, Y.; Kitao, O.; Nakai, H.; Vreven, T.; Montgomery, J. A.; Peralta, J. E., Jr.; Ogliaro, F.; Bearpark, M.; Heyd, J. J.; Brothers, E.; Kudin, K. N.; Staroverov, V. N.; Kobayashi, R.; Normand, J.; Raghavachari, K.; Rendell, A.; Burant, J. C.; Iyengar, S. S.; Tomasi, J.; Cossi, M.; Rega, N.; Millam, J. M.; Klene, M.; Knox, J. E.; Cross, J. B.; Bakken, V.; Adamo, C.; Jaramillo, J.; Gomperts, R.; Stratmann, R. E.; Yazyev, O.; Austin, A. J.; Cammi, R.; Pomelli, C.; Ochterski, J. W.; Martin, R. L.; Morokuma,
K.; Zakrzewski, V. G.; Voth, G. A.; Salvador, P. Dannenberg, J. J.; Dapprich, S.; Daniels, A. D.; Farkas, O.; Foresman, J. B.; Ortiz, J. V.; Cioslowski, J.; Fox, D. J. Gaussian 09, Gaussian, Inc., Wallingford, CT, 2009. 